\title{
The Impact of Human Resources Development and Organizational Culture on Employee Performance
}

\author{
E. Kosmajadi \\ Management of Islamic Education, Majalengka University, West Java, Indonesia \\ e.kosmajadi@gmail.com
}

\begin{abstract}
Research is motivated by the phenomenon of low employee performance, presumably due to suboptimal human resource development and a less conducive organizational culture. The study aims to identify and analyze: $a$. human resource development, organizational culture, employee performance; $b$ ) the magnitude of the influence of human resource development on employee performance; $c$ ) the importance of the impact of organizational culture on employee performance; and the extent of the effect of human resource development and organizational culture on employee performance. This research uses a quantitative approach with a survey method. The data collection tool used a questionnaire distributed to 44 employees. The data obtained were analyzed descriptively and through a statistical process. The results showed: a. From the results of descriptive analysis of human resource development, organizational culture and employee performance are in good condition, but there are weaknesses in certain aspects. The results of the verification analysis show; b) human resource development has a significant effect on employee performance with a magnitude of influence of 66.69\%; c) organizational culture has a significant impact on employee performance with the importance of the result of $51.84 \%$; and d) the development of human resources and organizational culture together have an effect on employee performance with the magnitude of the influence of $78.30 \%$, the remaining $21.70 \%$ is influenced by other factors that are not included in the model. In conclusion, both partially and simultaneously, human resources and organizational culture's development affects employee performance.
\end{abstract}

Keywords

human resource development; organizational culture; employee performance

\section{Introduction}

In an organization, both government and business organizations, human resources have a strategic role because other resources will not help humans. Therefore, human resources management is essential so that every organization or agency is always equipped with a staffing division. In simple terms, human resources are people as members of an organization who are commonly referred to as personnel, employees, employees or members. Specifically, inhuman government agencies are called employees who must be treated humanely and need to be adequately managed to be empowered to achieve organizational goals effectively and efficiently (Hanggraeni, 2012; Mangkunegara, 2001; Dipang, 2013). Philosophically, human resources are an investment that must be appropriately managed to be empowered and create a balance between the needs of employees and organizational needs, which has implications for proper HR planning to hold the right position (Jones and Walters, 2009; Sofyandi, 2013). In general, the management of human resources (employees) begins with the withdrawal, selection, 
development, maintenance, and use of human resources to achieve individual and organizational goals, providing compensation, ensuring work safety, assessment, and termination of employment (Handoko, 2011; Dessler, 2015; Sutrisno, 2015).

After human resources become part of an organization or agency with employee status, management will continue, significantly increasing competence and quality. Nowadays, all organizations are dealing with ongoing social changes. For employees who devote themselves to government, institutions must provide excellent service to the community. Thus, the development of human resources, which is the superior's duty and authority, is necessary.

Business activities can grow and develop for a long period of time is the goal of each company. Competitiveness, innovation, creativity, and the quality of the products produced must be in accordance with the needs of consumers and can adapt to a dynamic environment (Rosmadi, 2018). Kuswati (2019) stated that in the world of work, employees are required to have high work effectiveness. Organizational effectiveness is usually interpreted as the success achieved by an organization in its efforts to achieve predetermined goals. According to Werdhiastutie et al (2020) the development of human resources should focus more on increasing productivity and efficiency. This can be realized because today's competition, especially among nations, is getting tougher and demands the quality of strong human resources as managers and implementers in an organization or institution.

Management and development of Human Resources are essential because it is urgent to increase the institution's competitiveness, which can be done in various ways to improve knowledge, insight, and skills to increase the institution's productivity and quality. (Krismiyati, K, 2017; Aryana at.all, 2017; and Widiansyah, 2018). Dipang, L's (2013) research shows that human resource development has a significant effect on improving employee performance. Thus, it can be explained that to increase the competitive advantage of an institution, it is necessary to develop human resources to improve performance. If it is not done, employees will not show good performance due to limited competence. However, to achieve organizational goals properly through employee performance, other factors also affect employee performance, namely organizational culture. Organizational culture has benefits as an adhesive and a reference for employee behaviour. Organizational culture is a mutually agreed value system within an organization that differentiates it from other organizations. The agreed values and norms direct each member of the organization's behaviour to be maintained and maintained as a distinctive organizational identity. (Hendra, 2020; Robbins, 2013; Luthan, 2006; Mas'ud, 2004). To measure the extent to which the condition of the organizational culture is seen from several indicators as stated by Robbinhs and Judge (2011), namely in terms of individual initiatives, tolerance for risky actions, direction, integration, management support, supervision, identity, reward systems, patience to conflict, and pattern communication. From this quote, if an individual initiative is combined with management support by other aspects, the management will synergize employees' performance.

Performance has a meaningful relationship with job performance, which illustrates the achievement of implementing a task carried out by employees to realize organizational goals. The manifestation of this performance can be seen by comparing the input given with the output provided by three factors: individual, psychological, and organizational. The manifestation can be seen from several indicators: quality, quantity attitudes, attitudes, attitudes, and efficiency. (Moeheriono, 2014); Agustini, 2011; Mangkunegara, 2014; and Sutrisno, 2014). Thus, to improve employee performance, a human resource development program is needed following a conducive organizational culture system. Based on a review 
of the theoretical framework that describes the relationship between the variables studied, the following research hypotheses are proposed:

1. The influence of human resource development on employee performance.

2. There is an influence on the organizational culture of the employees' organization.

3. The influence of developing organizational resources and culture together on employee performance.

\section{Research Methods}

The research is located at the Sumedang Regional Library and Archives Office, with the main study relating to the science of public policy focused on human resource management. This research uses a quantitative approach with descriptive and verification methods - data collection techniques through distributing questionnaires to 44 respondents. The data obtained were processed and analyzed using a parametric statistical system, analyzed using descriptive and verification methods. Data processing and analysis were carried out through testing requirements analysis in validity and reliability tests, data normality testing, and hypothesis testing.

\section{Results and Discussion}

The data obtained by distributing questionnaires were processed and analyzed, descriptive and verificative. First, the results of descriptive analysis of the data obtained through questionnaires are as follows:

Table 1. Recapitulation of Percentage of Respondents' Responses

\begin{tabular}{|c|c|c|c|c|c|c|c|c|c|c|}
\hline \multirow{2}{*}{ No } & \multirow{2}{*}{ Variable } & \multirow{2}{*}{ Item } & \multicolumn{3}{|c|}{ Highest } & \multicolumn{3}{|c|}{ Lowest } & \multicolumn{2}{|c|}{ Rate } \\
\hline & & & No & $\%$ & Criteria & No & $\%$ & Criteria & $\%$ & Criteria \\
\hline 1 & HR Development & 13 & 10 & 84.54 & $\begin{array}{l}\text { Very } \\
\text { good }\end{array}$ & 8 & 65.90 & Enough & 72.87 & Good \\
\hline 2 & $\begin{array}{l}\text { Organizational } \\
\text { culture }\end{array}$ & 16 & 11 & 85.00 & $\begin{array}{l}\text { Very } \\
\text { good }\end{array}$ & 4 & 66.36 & Enough & 75.63 & Good \\
\hline 3 & $\begin{array}{l}\text { Employee } \\
\text { Performance }\end{array}$ & 14 & 3 & 85.40 & $\begin{array}{l}\text { Very } \\
\text { good }\end{array}$ & 8 & 65.45 & Enough & 74,06 & Good \\
\hline
\end{tabular}

Source: data analysis (2020)

From the data listed in table 1 , the analysis results show that each variable can explain the phenomenon. For the human resource development variable, respondents' perceptions are generally in good condition. The indicators of salary increases and allowances given according to the new rank's, with the proportion reaching $84.54 \%$, are in the excellent category. However, there is a weakness in the indicator of the frequency of employees participating in workshop activities, with a proportion of only $65.90 \%$ in the excellent category. This means that the research results can explain that human resources at the Regional Archives and Libraries Service Office have been implemented correctly. Still, there are minor weaknesses in specific indicators. The same analysis results show that the respondents' perceptions are generally conducive to organizational culture variables, especially on strict control indicators through several regulations or SOPs, with the proportion reaching $85.00 \%$ in the excellent category. The lowest percentage of the hands suggested taking risks for employees only got $66.36 \%$, with a good variety. This means that the research results can explain that the Regional Archives and Libraries Service 
organization is excellent and conducive. However, there are still minor weaknesses in specific indicators.

The employee performance variable is in good condition as evidenced by the respondents' perceptions, especially on the indicators of employee work implementation by prioritizing the number of products that reached the proportion of $85.45 \%$ with the excellent category. However, there are still weaknesses in employee work implementation indicators, always trying to reduce losses or failures, only $65.45 \%$ in the excellent category. This means that the research results can explain that, in general, the performance of the employees of the Regional Archives and Libraries Service is in excellent condition. However, there are still minor weaknesses in specific indicators. Thus, the study results explain the phenomena, which defects are not in their entirety, but only in particular indicators that are empirical findings of each variable. These findings will be instrumental for managers to be taken into consideration in efforts to improve organizational quality. Quantitatively, the data were analyzed using a parametric statistical approach. Done first before testing the analysis requirements shows that the data obtained is valid and reliable, and the distribution of data is usually distributed, as illustrated in table 2 below.

Table 2. Recapitulation of Percentage of Respondents' Responses

\begin{tabular}{llccccccccc}
\hline \multirow{2}{*}{ No } & \multirow{2}{*}{ Variable } & \multicolumn{3}{c}{ Validity } & \multicolumn{4}{c}{ Reliability } & \multicolumn{5}{c}{ Normality } \\
& & r-smallest r-table & Criteria & r-smallest r-table & Criteria & $\alpha$-table & $\alpha$ - table & Criteria \\
\hline 1 & HR Development & 0.376 & 0,300 & Valid & 0,891 & 0,700 & Reliable & 0,093 & 0,05 & Normal \\
2 & $\begin{array}{l}\text { Organizational } \\
\text { culture }\end{array}$ & 0.361 & 0,300 & Valid & 0,855 & 0,700 & Reliable & 0,118 & 0,05 & Normal \\
3 & $\begin{array}{l}\text { Employee } \\
\text { Performance }\end{array}$ & 0.330 & 0,300 & Valid & 0,889 & 0,700 & Reliable & 0,094 & 0,05 & Normal \\
& & & & & & & & & &
\end{tabular}

Source: data analysis (2020)

From the processing and analysis process with a parametric statistical approach through correlation, regression, and hypothesis testing, the results are as shown in Table 3 below:

Table 3. Hypothesis Testing Results

\begin{tabular}{|c|c|c|c|c|c|}
\hline \multirow[b]{2}{*}{ No } & \multirow[b]{2}{*}{ Structural } & \multicolumn{3}{|c|}{ Test result $\mathrm{t} / \mathrm{F}$} & \multirow[b]{2}{*}{ Decision } \\
\hline & & $\begin{array}{l}\text { Correlation } \\
\text { coefficient }\end{array}$ & $\mathrm{t} / \mathrm{F}$-value & $\mathrm{t} / \mathrm{F}$-table & \\
\hline 1 & $p_{y x 1}$ & 0,813 & 7,080 & $0,000^{\mathrm{a}}$ & $\begin{array}{l}\text { H0 is rejected, there is a significant } \\
\text { effect of HR development on employee } \\
\text { performance }\end{array}$ \\
\hline 2 & $p_{\mathrm{yx} 2}$ & 0,720 & 4,812 & $0,000^{\mathrm{a}}$ & $\begin{array}{l}\mathrm{H} 0 \text { is rejected, there is a significant } \\
\text { effect of organizational culture on } \\
\text { employee performance. }\end{array}$ \\
\hline 3 & $p_{\mathrm{yx}_{1} \mathrm{x}_{2}}$ & 0,885 & 73.996 & $0,000^{\mathrm{a}}$ & $\begin{array}{l}\mathrm{H} 0 \text { is rejected, there is a significant } \\
\text { effect of HR development and } \\
\text { organizational culture on employee } \\
\text { performance. }\end{array}$ \\
\hline
\end{tabular}

Source: data analysis (2020)

The hypothesis testing results show that the human resource development variable has a positive and significant effect on employee performance with the amount of influence of $66.09 \%$. Organizational culture variables have a positive and significant 
impact on employee performance with a magnitude of $51.84 \%$. The variables of human resource development and organizational culture together have a positive and significant effect on employee performance, emphasizing the influence of $78.30 \%$. From the research results, it can be explained that human resource development affects employee performance; even compared to organizational culture, it has a more significant influence. Logically, it is easy to understand because, in essence, management is a manager's effort to achieve goals by using other people to make management's primary potential human. So, suppose humans are developed as a whole, in the sense that it includes aspects of knowledge, skills, attitudes, morals, mental, and commitment in an integrated manner. In that case, it will encourage an employee to work better and professionally. This is in line with Ameeq and Hanif's (2013) research that employee empowerment, job design, teambased production systems, training and performance-based compensation are believed to be part of human resource management activities that can improve employee performance which has an impact on company performance. Empirically, from the findings of research on human resource development, there are minor weaknesses, namely the frequency of employees attending workshops, which is still low according to respondents' perceptions. This information can be taken into consideration for managers to strengthen human resource development, which will impact employee performance.

Organizational culture affects employee performance, which is logically easy to understand because organizational culture is part of the environment in which humans work. No matter how good an employee's competence is, an employee cannot carry out his duties and obligations without being provided with an appropriate place and environment. The environment is divided into two main parts, namely the physical and non-physical environments. The organizational culture is part of the non-physical environment, including external factors that affect employee performance. Therefore, a good work culture will have a good impact on employee performance. This study's results reinforce Wardani's (2016) research results, which shows that organizational culture affects employee performance by up to $51.84 \%$. Besides, the results of the study are in line with Schein's theory in Riani (2011), that organizational culture is a basic assumption pattern created and developed by a group so that organizations can learn to deal with problems that arise as a result of internal adaptation and external integration that has gone well. Then there must be a process of inheriting values to new employees to be able to adapt and become part of the organization internally, which will impact improving employee performance. Empirically, from the findings of organizational culture research, there are minor weaknesses, namely concerning managers 'suggestions for employees to dare to take risks which are still low according to respondents' perceptions; this information is helpful for managers to be taken into consideration to improve the quality of organizational culture. The two independent variables in this study each had a partially positive influence on the performance of the Regional Archives and Library Service of Sumedang Regency employees. If the two are combined, it is predicted to have a more significant influence; it turns out that the research proves that simultaneously it has an effect of $78.30 \%$. Other factors outside the model influence the remaining $21.70 \%$. This shows that to create good performance, managers need to pay attention to the balance between internal and external factors and other organizational factors. Empirically, from the findings of employee performance research, there are minor weaknesses, namely concerning employee work implementation, always trying to reduce losses, which is still low according to the respondent's perception. This information helps managers be taken into consideration to improve employee performance in addition to other factors. 


\section{Conclusion}

From the results of this study, qualitatively, each observed variable was in good condition, but there were still minor weaknesses in certain aspects. From the quantitative analysis, the results show that both partially and simultaneously, the development of human resources and organizational culture affects the performance of the Regional Archives and Library Service of Sumedang Regency employees. Based on the conclusion, managers are advised to improve aspects that are still weak by 1 - strengthening top management support in facilitating employees' self-development; 2 . Strengthen the recommendation for employees to be more courageous in taking risks in implementing work to provide room for movement so that employees can develop their innovation and creativity; 3 . Strengthening Standard Operational Procedure (SOP) to balance the courage to take risks with the intention that employees always try to reduce work losses or failures. If carried out in an integrated manner, these three suggestions are precious in improving employee performance, which positively impacts the quality of public services. The Regional Archives and Libraries Service's existence has the primary function of service to archive users and library users.

\section{References}

Aryana, I.N, Warnada, I.M, dan Yasa, N.N.K (2017) Membangun Keunggulan Bersaing Melalui Kinerja Sistem Informasi dan Customer Intimacy dalam Meningkatkan Kinerja Pemasaran, 6(4), 1343-1364.

Ameeq, A. \& Hanif, F. (2013). Impact of training on employee's development and performance in the hotel industry of Lahore, Pakistan. Journal of Business Studies Quarterly, 4(4), 68-82.

Agustini, F. (2011) Manajemen Sumber Daya Manusia, Medan: Madenatera.

Dipang, Ludfia (2013). Pengembangan Sumber Daya Manusia dalam Peningkatan Kinerja Karyawan pada PT Hasirat Abadi menado, 1(3),1080-1088.

Hanggraeni, Dewi. (2012). Manajemen Sumber Daya Manusia, Jakarta:LPFEUI.

Hendra (2020). Pengaruh Budaya Organisasi, Pelatihan, dan Motivasi Terhadap Kinerja Karyawan pada Universitas Cut Nyak Dhien Medan, 3(1), 1-13.

Jones, J.J dan Walters, D.L (2009) Human Resources Management in Education, Yogyakarta: Q-Media.

Krismiyati, K (2017) Pengembangan Sumber Daya Manusia dalam Meningkatkan Kualitas Pendidikan di SD Negeri Inpres Angkasa Biak, 3(1), 43-50.

Kuswati, Y. (2019). Motivation Role in Improving Work Effectiveness. Budapest International Research and Critics Institute-Journal (BIRCI-Journal). P. 281-288.

Luthan, F (2006). Perilaku Organisasi, Yogyakarta: Andi.

Mangkunegara, A.A.P (2001) Manajemen Sumber Daya Manusia Perusahaan, Bandung: PT Rosda Karya.

Refika Aditama.

(2014) Evaluasi Kinerja Sumber Daya Manusia, Bandung:

Mas'ud, F. (2004) Survai Diagnosis Organisasional (Konsep dan Apliaksi), Semarang: Universitas Diponegoro.

Moeheriono (2014) Pengukuran Kinerja Berbasis Kompetensi (Revisi), Jakarta: PT Raja Grafindo Persada.

Riani, Asri Laksmi. 2011. Budaya Organisasi, Yogyakarta : Graha Ilmu. 
Robbin, S.P (2013). Perilaku Organisasi, Konsep, dan Kontroversi, Aplikasi, Jakarta: Prenhalindo.

Rosmadi, M.L.N. (2018). Factors in Developing Creative Industry. Budapest International Research and Critics Institute-Journal (BIRCI-Journal). P. 64-69.

Sutrisno (2014) Manajemen Sumber Daya Manusia, Jakarta: Kencana Prenada Media Group.

Wardani, Rodiathul Kusuma, Mukzam, M. Djudi, dan Mayowan, Yuniadi. (2016). Pengaruh Budaya Organisasi Terhadap Kinerja Karyawan (Studi Pada Karyawan PT Karya Indah Buana Surabaya), 31(1), 58-65.

Werdhiastutie, A., et al. (2020). Achievement Motivation as Antecedents of Quality Improvement of Organizational Human Resources. International Research and Critics Institute-Journal (BIRCI-Journal). P. 747-752.

Widiansyah, A (2018). Peranan Sumber Daya Manusia Pendidikan sebagai Faktor Penentu dalam Manajemen Sistem Pendidikan, 18(2), 299-234. 